\title{
Adaptive Water Management-land Use Practice for Improving Ecosystem Services - a Hungarian Modelling Case Study
}

\author{
Zsolt Kozma $^{1 *}$, Zsolt Jolánkai ${ }^{1}$, Máté Krisztián Kardos ${ }^{1}$, Bálint Muzelák${ }^{1}$, László Koncsos ${ }^{1}$ \\ ${ }^{1}$ Department of Sanitary and Environmental Engineering, Faculty of Civil Engineering, Budapest University of Technology and \\ Economics, H-1521 Budapest, P.O.B. 91, Hungary \\ * Corresponding author, e-mail: kozma.zsolt@emk.bme.hu
}

Received: 16 April 2021, Accepted: 31 October 2021, Published online: 18 November 2021

\begin{abstract}
During the $20^{\text {th }}$ century in the Hungarian lowlands the emphasis was put on maximizing provisioning ecosystem services (ES), which caused the weakening of regulating and other services. With the growing environmental pressures, it is crucial to apply a more adaptive landscape management. This, however, leads to territorial conflicts, as large areas with water-tolerant land cover (i.e., wetlands, meadows, riparian forests) are needed to buffer extreme hydrological events.

We present some findings of the WateRisk project, a research that focused on the possible solutions of these conflicts. In a scenariobased case study, we analyze the outlined issue for the Szamos-Kraszna Interfluve, a $510 \mathrm{~km}^{2}$ lowland catchment heavily affected by excess water. Scenarios were evaluated with an integrated methodology that focuses on the water budget and the total values of ES. The efficiency of the drainage network was found to be minor/moderate as it provided only $-1-5 \%$ reduction in the spatial extents of inundations, and it contributed only $\sim 20 \%$ to the elimination of water coverage. Furthermore, comparing the present (defensefocused) and the alternative (water retention focused) scenarios, the latter turned out to provide higher monetary value for the summed individual and social benefits of ES. This underlines the need for extensive adaptive measures in both water management and landscape planning to create resilience and the ability to cope with contemporary environmental challenges.
\end{abstract}

Keywords

hydrological modelling, ecosystem services, excess water, land use change, natural water retention measures

\section{Introduction}

One of the main and permanent challenges of the Hungarian water management sector is the "water surplus-water scarcity". This is a paradoxical hydrological situation, when inland excess water (IEW, ponding water, waterlogging) and drought occurs consecutively in the same locations within years or even seasons. While drought is a well-known hydrological problem, inland excess water occurs only in specific lowland geographical locations. According to the most general definition [1], excess water is a temporal water surplus, which can appear either as surface water coverage and/or fully saturated root zone. The phenomenon is caused by the combination of heavy precipitation, snowmelt, groundwater upwelling as well as insufficient evapotranspiration, runoff and infiltration. Both hydrological extremities affect virtually the whole Great Hungarian Plain (GHP, $43,600 \mathrm{~km}^{2}$ ), with excess water hazard being moderate or high roughly on $10 \%$ of the GHP [2]. Natural (climatological, morphological, hydrogeological) factors as well as land use and water management practice induce the excess water - drought cycles: the affected lowlands are alluvial plains, which have undergone significant landscape modifications in the $18-19^{\text {th }}$ centuries [3]. Besides the major river regulations, the frequently inundated wetlands of the region were drained to provide space for agricultural production. As a result, Hungary became a significant cereal producer in the region [4]. However, the long term negative consequences of this endeavor are also obvious by now: (i) an extensive flood- and excess water defense system is maintained by the state to provide tolerable/near-optimal conditions for rainfed crop cultivation; (ii) this drainage system diverts valuable surface and subsurface water resources out from the country leading to tendentious decrease in groundwater levels [5]; (iii) this trend is unfavorable for the ecological status of both the surface and the subsurface water bodies. (iv) and contrary to that, annual grain yields are highly exposed to climatic factors and groundwater availability [5]. 
Szesztay [6] interpreted this problem in an integrated way already a quarter century ago. He pointed out the importance of forested areas in Hungary and especially on the Great Plain, as these provide a significant buffering capacity both for hydrological and water quality processes. The outlined land use-water management problem can also be interpreted within the ecosystem services (ES) framework [7]. The private and social utilization of natural capital of a region results in trade-offs between provisioning, regulating and cultural services [8]. In the case of the GHP this basically means that the territorial and technological intensification of agricultural production (provisioning ES) led to the weakening of several other ES [9]. The latter include most importantly the buffering capacity of the landscape to mitigate hydrological extremities (riverine flood, inland excess water and drought) and thus indirectly improve agricultural yields; but carbon sequestration, microclimate regulation, water quality control and many cultural services can also be mentioned.

Several ES studies concluded that alternative land use systems - focusing more on climate adaptation and regulating services - could lead to higher social benefits than present conditions [10-12]. This is in line with empirical evidence and with policy recommendations as well: both emphasize the importance of water retention and wetland restoration efforts (e.g., [13-15]). Careful planning is needed however to find a more beneficial ratio between provisioning and regulating services. There is a continuous and intense debate about how to find the appropriate way to reform land use and water management in the GHP. A number of environmental characteristics (surface morphology, river and channel network, soil properties, geology) pose physical constraints, within which individual and community decisions can take place. To partially overcome this knowledge gap, [16] analyzed the willingness of local farmers for cooperation in order to minimize the cost of obligatory land use change in a lowland catchment prone to excess water. The ecological focus areas requirement of the EU served as the external obligatory driving force, which states that $7 \%$ of arable land must be converted to ecologically more beneficial land covers (woodland, meadow, wetland). Besides novel policy instruments (auction) hydrological modelling was successfully used to identify the socio-economically and environmentally most suitable areas for cooperative land use change, which would reduce the costs of conversion by up to $38 \%$.

In this study, our goal was to present a similar research but for a more ambitious land use change approach and with a more explicit evaluation of different ES. Using modelling tools, we aimed to (i) evaluate the performance of an excess water drainage network, and (ii) quantify the relevant ES for a set of different land use-water management scenarios, in order to compare a provision-maximizing and an adaptation-focused strategy. The novelty of the research is that it settles - at least for the study site and similar catchments - a fundamental expert debate in relation with the importance of the drainage network and its contribution to excess water mitigation. As part of this, we managed to calibrate an integrated hydrologic model in a lowland area not only for one, but for several hydrologic variables. A further innovation is that we evaluated ES with a fine spatio-temporal resolution for long periods of time and with respect to simulated hydrological conditions for a heavily modified lowland catchment. Similar hydrological and ES analyses are still scarce for the former wetlands and alluvial plains of the Tisza river valley.

\section{Materials and methods}

We carried out the analysis in three consecutive steps: First, a set of scenarios was developed for the SzamosKraszna Interfluve, a $510 \mathrm{~km}^{2}$ lowland catchment heavily affected by excess water (Sections 2.1 and 2.2). The aim of these scenarios was model calibration, the analysis of the drainage system and the comparison of two distinctly different land use - water governance strategies. Then, the WateRisk Integrated Hydrological Modell [17] was used to describe the fine resolution spatial-temporal changes of water resources along the scenarios (Section 2.3). Finally, several provisioning and regulating ES were quantified based on literature and with respect to the simulated water availability for the two different landscape use scenarios (Section 2.4). This methodology allowed us to assess the efficiency of the drainage network and to evaluate the performance of the two land use - water governance strategies.

\subsection{Study site}

The Szamos-Kraszna Interfluve is a $510 \mathrm{~km}^{2}$ lowland catchment in North-Eastern Hungary (Fig. 1). The area was a famous marshland (the marsh of Ecsed) before it was drained to be adapted mostly to intensive agricultural production (Table 1). Ever since, an extensive drainage network is maintained to mitigate excess water: the drainage density is $2.31 \mathrm{~km} / \mathrm{km}^{2}$, and dozens of control structures govern water movement in the channels).

However, field experience shows that the channel system is only capable to mildly reduce the size and duration of the water coverage but cannot eliminate it. Thus, 


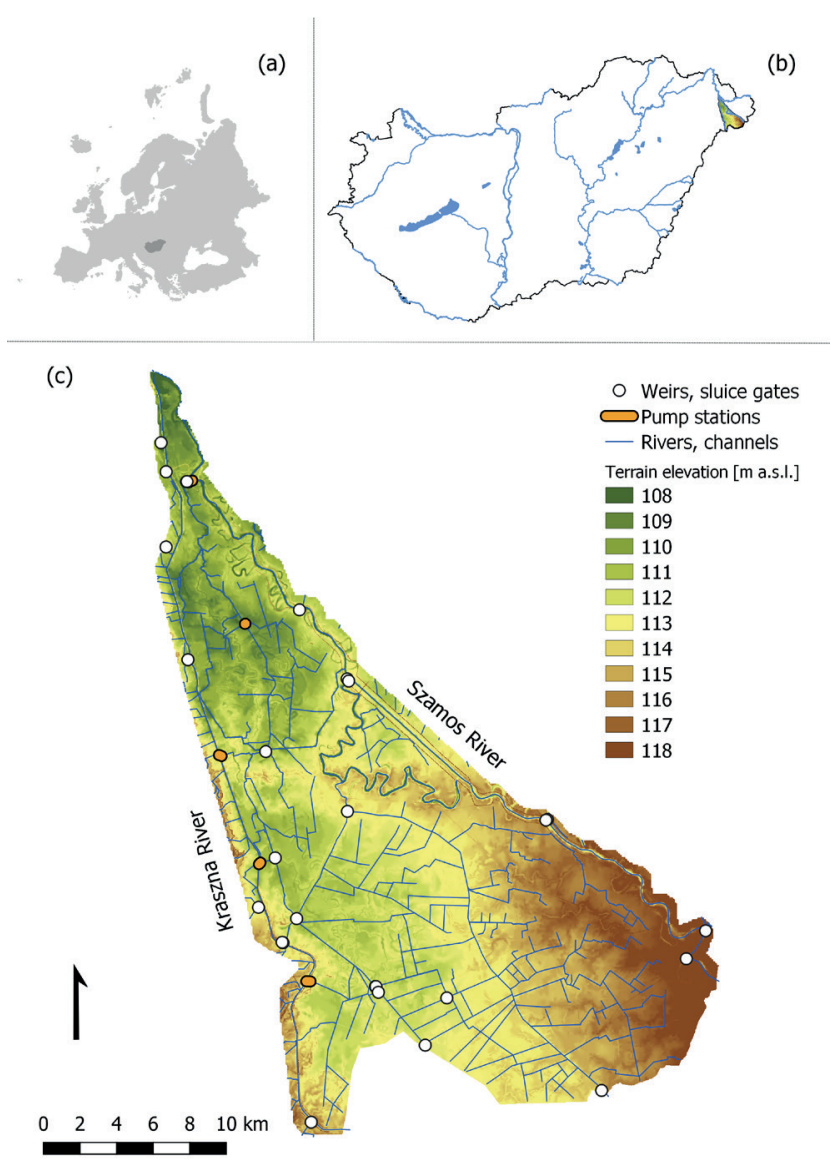

Fig. 1 The Szamos-Kraszna Interfluve; (a)-(b) Geographical location, (c) Terrain elevation, channel-network, control structures, pump stations

Table 1 Spatial ratio of the main land use-land cover types for the reference and alternative scenarios

\begin{tabular}{lcc}
\hline \multirow{2}{*}{ Land use-land cover type } & \multicolumn{2}{c}{ Scenario } \\
& Reference & Alternative \\
\hline Artificial & $5 \%$ & $4 \%$ \\
Cropland & $73 \%$ & $34 \%$ \\
Orchard, other agricultural & $7 \%$ & $5 \%$ \\
Pasture, grassland & $9 \%$ & $12 \%$ \\
Forest & $4 \%$ & $35 \%$ \\
Wetland & $0 \%$ & $8 \%$ \\
Water bodies & $3 \%$ & $2 \%$ \\
\hline
\end{tabular}

the area is affected with excess water almost every year. Small terrain relief $(0.25 \mathrm{~m} / \mathrm{km})$, the flow regime of the bordering rivers, mostly silty and clay soils and regional groundwater discharge are the defining factors in this. As part of the Improvement of the Vásárhelyi Plan [18] an emergency overflow reservoir was built in the northern part of the study site to reduce the flood risk of the Upper-Tisza region. The constructions were finished in 2014 and enabled the $51 \mathrm{~km}^{2}$ large reservoir to divert and temporally store a maximum of 126 million $\mathrm{m}^{3}$ water from the Szamos river. The facility was designed to mitigate near-catastrophic situations, thus it has not been operating ever since the inauguration and only minor land use change happened in the reservoir area.

In our analysis we did not take into account this facility as most of the relevant excess water observations were recorded prior to it's construction.

\subsection{Scenarios}

As part of the WateRisk project a set of climate-land use-water management scenarios were elaborated for three pilot areas [19]. In this paper, we analyze the following four cases for the Szamos-Kraszna Interfluve:

1. Present-reference:

Aim: calibration of the hydrological model, evaluation of the drainage network, creation of excess water hazard map.

Time period: 1980-2010;

Hydro-meteorological data: measured.

Drainage network: fully operating.

Land use: recent conditions ([20], Fig. 2, left)

2. Present-without drainage:

Aim: the evaluation of the drainage network. Time period: 1980-2010;

Hydro-meteorological data: measured.

Drainage network: pump stations and regulation structures are disabled, increased channel roughness. Land use: recent conditions ([20], Fig. 2, left)

3. Control-reference:

Aim: the evaluation of ES.

Time period: 1961-1990;

Hydro-meteorological data: downscaled IPCC Control [21].

Drainage network: fully operating.

Land use: recent conditions ([20], Fig. 2, left)

4. Control-alternative:

Aim: the evaluation of ES.

Time period: 1961-1990;

Hydro-meteorological data: downscaled IPCC Control [21].

Drainage network: pump stations and regulation structures are disabled, increased channel roughness, modified channel network.

Land use: adaptive land use (Fig. 2, right)

Fig. 2 and Table 1 compare the actual and proposed alternative land use-land cover conditions. The actual conditions were derived from the Corine Land Cover 2000 dataset [20]. The central idea of the alternative landscape map 


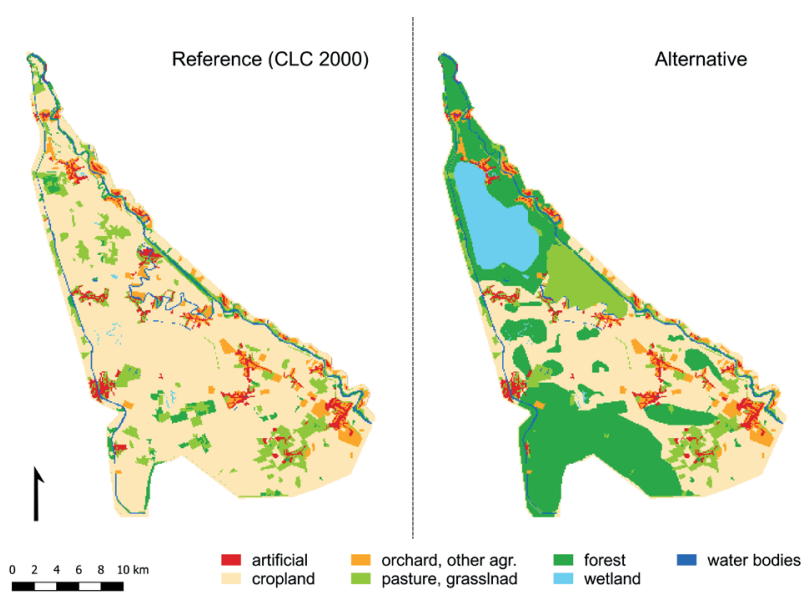

Fig. 2 Recent (left) and adaptive (right) land use-land cover maps of the study site

was the historical floodplain management in Hungary [3]. To design a modern form of this traditional, adaptive resource utilization practice, the proportion of extensive land uses and water tolerant vegetation (pasture, meadow, forest, wetland) were significantly increased.

These land cover types were mostly located into deep lying and excess water sensitive areas. The large wetland in the Northern part of the area was operated as a flood reservoir, regularly receiving flooding water from the Szamos River.

A soil database developed by [22] was used to define the model parameters for the saturated and unsaturated zones. Other important model parameters (Manning roughness coefficient of the river bed, storage coefficient of the surface inundation module, leaf area index (LAI) and root zone depth for the vegetation type, etc.) were set according to relevant literature $[23,24]$. Table 2 summarizes the major input data types, their sources and the obtained information. For further details of model configurations see $([23,25])$.

\subsection{Hydrological model}

\subsubsection{Model setup and calibration-validation}

The WateRisk Integrated Hydrological Model (WR IHM) [17] was used to simulate the spatial-temporal processes of the water cycle. The WR IHM is a physically based, distributed parameter, fully coupled hydrologic model. It simulates the major processes regarding the land phase of the hydrologic cycle in a synchronized way. The simulated processes are evapotranspiration, interception, 1D channel and 2D overland flow as well as 1D unsaturated zone and $2 \mathrm{D}$ shallow groundwater movement. The solution of the governing equations is carried out either with analytical approximations or with a finite difference numerical scheme [26]. The model was used successfully in several case studies to describe the water budget of Hungarian lowland catchments [16, 25, 27-29]. As part of the Implementation of the Flood Directive it was also applied to derive the excess water hazard and risk maps of the Szamos-Kraszna Interfluve [23]. The calibration of integrated hydrological models is a challenging task,

Table 2 Summary of input data: data type, source, obtained information and spatial extend

\begin{tabular}{|c|c|c|c|}
\hline Data type & Source and reference & Obtained information & Spatial extend \\
\hline $\begin{array}{l}\text { Meteorological: } \\
\text { historical }\end{array}$ & $\begin{array}{l}\text { General Directorate of Water Management } \\
\text { (Hungary), Upper Tisza Water Directorate }\end{array}$ & $\begin{array}{c}\text { Daily precipitation, temperature and relative humidity } \\
\text { time series }\end{array}$ & Pointwise \\
\hline $\begin{array}{l}\text { Meteorological: } \\
\text { climate scenarios }\end{array}$ & Prudence project [21] & $\begin{array}{c}\text { Daily precipitation, temperature and relative humidity } \\
\text { time series }\end{array}$ & Pointwise \\
\hline $\begin{array}{l}\text { Hydrological } \\
\text { observations }\end{array}$ & $\begin{array}{c}\text { General Directorate of Water Management } \\
\text { (Hungary), Upper Tisza Water Directorate, } \\
\text { Lechner Nonprofit Kft. }\end{array}$ & $\begin{array}{l}\text { Daily boundary river stages and groundwater observations, } \\
\text { remote sensing maps of excess water }(1999,2000) \text {, excess } \\
\text { water frequency map (1998-2016), pumped water volume } \\
\text { time series }\end{array}$ & $\begin{array}{l}\text { Pointwise, } \\
20 / 25 \mathrm{~m} \text { raster }\end{array}$ \\
\hline $\begin{array}{l}\text { River and channel } \\
\text { network }\end{array}$ & $\begin{array}{l}\text { General Directorate of Water Management } \\
\text { (Hungary), Upper Tisza Water Directorate }\end{array}$ & $\begin{array}{c}\text { Location and geometry of the Szamos and Kraszna rivers } \\
\text { and the drainage channels (longitudinal and cross sections, } \\
\text { roughness conditions) }\end{array}$ & Polyline \\
\hline $\begin{array}{l}\text { Water } \\
\text { infrastructure }\end{array}$ & $\begin{array}{l}\text { General Directorate of Water Management } \\
\text { (Hungary), Upper Tisza Water Directorate }\end{array}$ & $\begin{array}{l}\text { Location and operational characteristics of hydraulic } \\
\text { structures (diameter, loss coefficient, pumping capacity, etc.) }\end{array}$ & $\begin{array}{l}\text { Pointwise, } \\
\text { polyline }\end{array}$ \\
\hline Terrain elevation & $\begin{array}{l}\text { Institute of Geodesy Cartography and } \\
\text { Remote Sensing (Hungary) }\end{array}$ & Digital elevation model of the terrain surface & $100 \mathrm{~m}$ raster \\
\hline Land use & CORINE Land Cover $[20,24]$ & $\begin{array}{l}\text { Land use map, plant specific parameters (surface roughness, } \\
\text { leaf area index, rooting depth) }\end{array}$ & $100 \mathrm{~m}$ raster \\
\hline $\begin{array}{l}\text { Soil and } \\
\text { geological }\end{array}$ & $\begin{array}{l}\text { 3D soil hydrological database elaborated } \\
\text { for the study site [22] }\end{array}$ & $\begin{array}{l}\text { Horizontal and vertical distribution of FAO soil types; } \\
\text { Mualem-van Genuchten soil hydraulic parameters }\end{array}$ & $\begin{array}{l}100 \mathrm{~m} \text { raster, } \\
0.1-0.5 \mathrm{~m} \text { layers }\end{array}$ \\
\hline
\end{tabular}


as the number of adjustable parameters is high (possible overfitting), and the significant time demand of simulations can limit the number of calibration runs (automated optimization might be technically impossible). On the other hand, the physical background and the improving environmental databases help the more reliable adjustment of the important parameters. Furthermore, as multiple state variables (see below) are calculated, the modeler has more options to check the agreement between simulation results and real world data. This is especially relevant for lowland catchments, where water coverage, groundwater and surface water levels offer multiple points of comparison. Thus, in this study we used the following data groups to carry out a manual parameter adjustment for the Present-reference scenario:

(i) water levels in the Szamos and Kraszna rivers

(ii) summed volume of pumped water

(iii) groundwater levels recorded at 5 monitoring wells

(iv) daily pan evaporation for 2010

(v) remotely sensed spatial coverage of excess water

For such model calculations, the initial conditions have long lasting (months to years) effects on simulation results, especially on surface water coverage and groundwater levels. Therefore, the calibration was done not on an event basis but by simulating multiyear periods that included the measurement intervals. For the same reason, validation was also done as part of continuous calculations. Calibration and validation were burdened with access to site- and process specific data. Major, relatively well-monitored excess waters occurred in 1999, 2000 and 2010. Therefore, 1999 and 2000 were chosen for calibration of EW coverage and pumped volumes, while 2010 as validation of the same variables. Measured pan evaporation was available only for the vegetation period of 2010. Groundwater measurements covered 1985-2000, thus we divided this period into two parts for parameter adjustment and validation.

To cope with data uncertainty, we performed a manual sensitivity analysis, which clearly showed that soil properties (capillarity and horizontal/vertical hydraulic conductivity) are the most sensitive parameters regarding all modelled variables [28]. Beside these, vegetation parameters, surface roughness, channel roughness and a site-specific empirical factor for evaporation were also involved in the sensitivity analysis. Mainly the sensitive soil parameters were subject to the manual calibration.

Table 3 summarizes calibration and validation results for common model efficiency statistics ( $\mathrm{R}^{2}$, RMSE, NashSutcliffe modell efficiency: NSME). The adjustment of
Table 3 Model efficiency measure results of the calibration-validation process

\begin{tabular}{lccc}
\hline Variable & & Calibration & Validation \\
\hline $\begin{array}{l}\text { River stage } \\
\text { (Kraszna, }\end{array}$ & $\mathrm{R}^{2}$ & 0.98 & 0.96 \\
Szamos) & $\mathrm{RMSE}[\mathrm{m}]$ & 0.22 & 0.58 \\
& $\mathrm{R}^{2}$ & $\{0.70 ; 0.92\}$ & $\{0.60 ; 0.81\}$ \\
Groundwater & $\mathrm{RMSE}[\mathrm{m}]$ & $\{0.40 ; 0.87\}$ & $\{0.42 ; 0.65\}$ \\
level at 5 wells & $\mathrm{NSME}$ & $\{-0.20 ; 0.80\}$ & $\{-1.21 ; 0.51\}$ \\
& $\mathrm{R}{ }^{2}$ & 0.82 & - \\
Daily & $\mathrm{RMSE}[\mathrm{mm}]$ & 1.01 & - \\
evaporation & $\mathrm{NSME}$ & 0.67 & - \\
& $\mathrm{R}{ }^{2}$ & $0.99 ; 0.98$ & 0.97 \\
$\begin{array}{l}\text { Cumulative } \\
\text { daily pumped }\end{array}$ & $\mathrm{R} R \mathrm{MSE}[\%]$ & $39 ; 45$ & 49 \\
water volume & $\mathrm{NSME}$ & $0.88 ; 0.84$ & 0.139 \\
$\begin{array}{l}\text { EWcoverage } \\
\text { accuracy }\end{array}$ & agree [\%] & 74.2 & 90.4 \\
\hline
\end{tabular}

pumped volume, groundwater levels and EW coverage proved to be the most challenging tasks [23]. First, reported water movement at pump stations showed rapid daily fluctuations, resulting from the actual local hydrologic and resource conditions as well as operator decisions at the pump stations. We were not able to represent this daily fluctuation with a hydrological model covering $510 \mathrm{~km}^{2}$ and more than $900 \mathrm{~km}$ channel network and using prescribed operational rules. Therefore, we decided to adjust the model for the cumulative time series of pumped water volume for each EW events. As the absolute pumped volumes are hard to interpret, in case of RMSE, we used relative values. Second, the monitoring wells are located within settlements, where local drivers (e.g., sewage desiccation typical in the period) can significantly influence measured groundwater levels. Finally, remotely sensed EW data are still uncertain [30] due to measurement challenges (spatial resolution, cloud coverage, etc.) and data processing (interpretation of spectral or radar data). Furthermore, only a small number of EW satellite maps were available, which did not make the usage of common model statistical measures meaningful. Thus, we compared the overall EW coverage for the available measurement times (Fig. 3) and performed one accuracy assessment for both 1999 and 2000.

\subsubsection{Modelling considerations about excess water}

Both extensive surface water coverage and fully saturated root zone conditions are usually considered as excess water. In case of cell-based hydrological simulations, however it is technically more precise and convenient to interpret the 


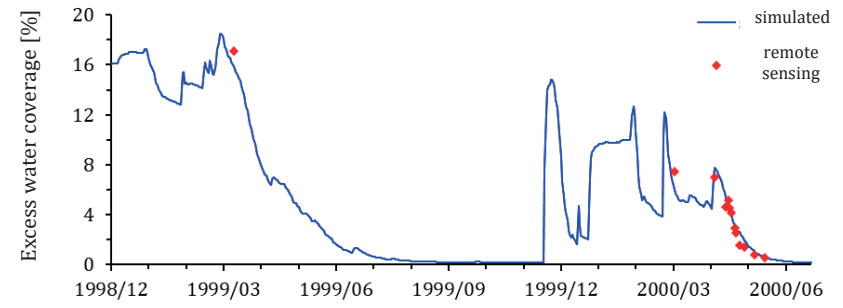

Fig. 3 Comparison of remotely sensed and simulated excess water coverages for the whole study site

study site scale condition of excess water only to the extent of water coverage. Therefore, we followed this logic for the processing of our simulation results.

After the simulation of the 30 years long Scenario 1 ("Present-Reference"), we selected major EW events for further water budget analysis. For this, we used a set of specific criteria/thresholds. According to field experience and our simulation results, there is no single plot for the formation of EW. Instead, various - seemingly not critical - combinations of the causes (snow accumulation and snowmelt, soil frost, significant amount of precipitation) can lead to severe inundations. Therefore, instead of one or more forcing factors (e.g., extreme precipitation events) we used the spatial extent and temporal duration of surface water coverage for the selection of the major EW events and the exclusion of minor events. Only those inundations were shortlisted for further investigation, which affected at least $2 \%$ of the pilot area and lasted for more than 10 consecutive days (with temperatures above $0{ }^{\circ} \mathrm{C}$ ). These thresholds were chosen after a manual sensitivity analysis, The minimum, average and maximum lengths of the selected events were 12, 97 and 351 days respectively. The minimum, average and maximum values of simulated runoff coefficient (runoff/precipitation) were 0.14, 0.32 and 0.64 respectively. The long-term annual value of simulated runoff coefficient was 0.16 , which is in line with the values reported from field measurements [31].

There is a long-lasting debate about the effectiveness and utility of the excess water drainage network. The most important issues are: Question (i) in what proportion do the channels drain surface and subsurface water resources; Question (ii) how do natural and artificial processes influence the disappearance of the surface water coverage; Question (iii) does the drainage system have a major effect on the maximal spatial extent of inundation as well, or only on its temporal duration. The process based hydrological model simulations enabled us to find site specific answers for these questions. For each of the selected 23 events, a water budget was set up, which quantified the absolute and relative weight of all modelled storage and flux components. Based on these water budgets we could answer questions (i) and (ii). Then, we compared the simulated total water coverage time series for the Scenario 1. and the Scenario 2. (Present-without drainage). As the only difference between these scenarios was the presence/absence of the drainage network, question (iii) about its effectiveness is directly quantified by the difference of water coverage time series.

\subsection{ES evaluation}

We selected a group of provisioning and regulating ecosystem services for quantification, which (i) are strongly influenced by the availability of water resources and (ii) relevant for the typical conditions of alluvial plains in the Carpathian Basin.

Agricultural crop production is currently the most important provisioning ES of the region. We used a dynamic crop yield calculator integrated in the WR IHM to quantify cereal production [32]. The applied method is based on the logic described by [33] and calculates annual attainable crop production from site-specific potential yield data and simulated water availability. Thus, in our simplified approach, water surplus (saturated root zone, surface water coverage) or water shortage (significant difference between actual and potential transpiration) are the only considered limiting factors, whereas climate, soil, nutrient availability are taken into account via the value of potential production. Based on county-level statistical data, a 30:70 wheat-maize proportion was utilized in all scenarios [34]. Crop specific parameters were adjusted according to relevant Hungarian literature and historical yield data of $[32,34]$.

Several ES are linked to tree stands and forests, of which we quantified $\mathrm{CO}_{2}$ fixation as a function of simulated hydrological conditions. We did so by using a forestry module built into the WR IHM. This algorithm applies the common methodology of site categorization and yield tables, but as an additional feature, it uses hydrological simulation results as input data [35]. These are (i) the average groundwater level in April, (ii) the availability of water in the soil column and (iii) the duration of water coverage. Water availability influences estimated tree growth in two ways: First, in the determination of the site yield class (while climate type and soil type are site dependent, the hydrological category is determined with respect to simulation model result). Second via mortality control (tree stand mortality occurs in the case of extremely dry years 
or prolonged periods of water coverage). To simplify the analysis and reduce data uncertainty, white poplar (populus alba) was the only evaluated species. It is a common species across the GHP and due to its tolerance, it can be planted both in dry and humid sites.

Besides the explicit, hydrology-dependent quantification of crop yield and tree growth, we also relied on civil engineering and socio-economical studies to estimate the value of various ES of different land use types. Koncsos and Balogh [36] carried out a comprehensive flood damage estimation with the 2D hydrodynamic modelling of 30 deep floodplains along the Hungarian section of the Tisza river. Their risk based approach allowed the quantification of possibly avoidable flood risk, which we used to estimate the unit value of flood regulation of wetlands as an ES. Eszlári et al. [37] estimated both private and social costs and benefits for croplands, grazing lands, forests, wetlands and lakes and rivers. They derived their results for three lowland regions of the GHP by using cost-benefit analysis, contingent valuation and the benefit transfer method. We used the land use specific outcomes of their research to account for costs and benefits of regulating services.

\section{Results and discussion}

\subsection{Hydrological modelling}

\subsubsection{Model performance}

Calibration and validation proved to be challenging mainly due to high data uncertainty and because the high computational demand allowed only a manual approach. Even so, we were able to set up a versatile model, which offers a reasonable compromise of accuracy among the different hydrological variables of heavily modified lowland catchments (actual evaporation, surface water coverage, groundwater levels, drainage runoff). The general model accuracy (Table 3) was somewhat below the typical level of goodness-of-fit, which can be achieved by hydrological model applications. Generally, for catchments with at least moderate hillslope and with minimal or no groundwater feedback on surface processes, hydrological models can provide high precision simulations of runoff. For instance, for the small $\left(75.9 \mathrm{~km}^{2}\right)$ and flashy (time of concentration is less than 1 hour for all sub-catchments) Jičinka River catchment [38] set up a lumped (HEC-HMS) and distributed parameter (SHETRAN) hydrologic model and reported NSME between 0.88 and 0.95 for calibration and NSME between 0.53 and 0.91 for validation events. For the same catchment Đukić et al $[38,39]$ also presented that lumped and distributer parameter models can provide reasonable estimates also for soil moisture: both the cellbased maps and the catchment scale averages of simulated soil moisture showed good agreement with downscaled satellite data.

However, there are some defining differences between such model applications in hilly basins and the simulation of excess water in heavily modified lowland catchments. Latter are dominated by strong groundwater-surface water interactions and by the effects of drainage channels and water infrastructure. Elevated GW levels can lead to full saturation of soils and the temporal appearance of surface water coverage. Minimal terrain slopes and these occasional surface inundations cause ambiguous surface flow accumulation patterns. Flow routing in the channel network is burdened by strong groundwater seepage, by minimal slopes of the energy grade lines, by backwater effects and by occasional pumping.

To put these hampering factors into context, it's worth to note that most excess water modelling attempts focus only on one of the hydrological variables. [40] used the coupled MIKE SHE-MIKE 11 models to simulate runoff from a $290 \mathrm{~km}^{2}$ drained Hungarian lowland catchment. Over a 10 years period they achieved $\mathrm{R}^{2}=0.63$ on a monthly basis, while $\mathrm{R}^{2}=0.94$ for yearly summation as best results. The authors considered this estimate as acceptable for water balance purposes. However, they reported significant errors in case of daily comparison, especially for the two years with heavy EW inundations $(2006,2010)$. They explained these errors with insufficient data about the drainage network, which therefore was not properly incorporated into the model. As the authors aimed to simulate only runoff, they did not discuss surface water coverage or groundwater conditions.

van Leeuwen et al. [41] also used the MIKE SHE model to simulate the spatio-temporal changes of remotely sensed EW inundations. The analysis took place at a $39 \mathrm{~km}^{2}$ Hungarian catchment and focused on a one-month long EW event. The authors were able to reach a spatial accuracy above $75 \%$. However, in the lack of data, they did not check the model results for groundwater or for the drainage runoff.

\subsubsection{Excess water hazard map}

The 30 years long simulation results enabled us to derive the excess water hazard map of the study site (Fig. 4(b)) and compare it with empirical information about hazard: a satellite imagery based relative frequency map (Fig. 4(a)). The latter was created by the Lechner Nonprofit Kft. [42] 
for the whole country by combining a maximum number of eight Landsat, SPOT, IRS and Sentinel satellite images taken between 1998-2016. The processing was done only for cultivated lands eligible for subsidies from the common agricultural policy of the European Union (settlements, forests, wetlands were excluded). Besides surface water coverage, they also considered moderate and high topsoil saturation as excess water. However, this is a somewhat ambiguous aspect, as the background document does not specify, what level of saturation is considered as moderate and high. The main advantages of the hazard map are the underlying empirical data, the countrywide areal coverage and the fine $(10 \mathrm{~m})$ spatial resolution. Because of cloud cover and satellite revisit times, only 4-6 images were available for the study site. So, despite its' seemingly fine thematic resolution ( $10 \%$ steps), the map offers a rough relative frequency of surface water coverage and saturated topsoils, which is hard to interpret (what does e.g., the $>90 \%$ value mean, when the total number of evaluated events is only 6). Fig. 4(b) is the simulation based hazard map of the study site for the Scenario 1. In this case, hazard was interpreted as the probability of the extremity in a given cell [43]. It is calculated by dividing the number of days when surface water coverage occurred with the total number of days in the 30 years long simulation period. Thus, this map shows the probability of inundation by using a large statistical sample. As it is based on simulations, the resolution is the same as for the hydrological model: $100 \mathrm{~m}$. For the above-mentioned methodological differences (different thematic content, spatial resolution and temporal coverage) we compared the satellite imagery and simulation based hazard maps only in a qualitative manner for agricultural lands. Regarding the severity of the extremity, the general pattern is similar on the two maps. The effect of terrain differences and the drainage network are clearly recognizable on both maps. The satellite based map suggests larger areal concern and more severe hazard. The simulated hazard map offers a more mosaic pattern with sharper distinction in affected and unaffected areas. This is partially a result of the fact that only water coverage was considered during the calculation of hazard. Topsoil saturation was excluded because of its ambiguous interpretations: to our best knowledge, there isn't a clear consensus about what depth of topsoil and what level of saturation over what time period should be considered as excess water. By evaluating all limitations and uncertainties, we consider this comparison of hazard maps as an indirect validation of the simulations.

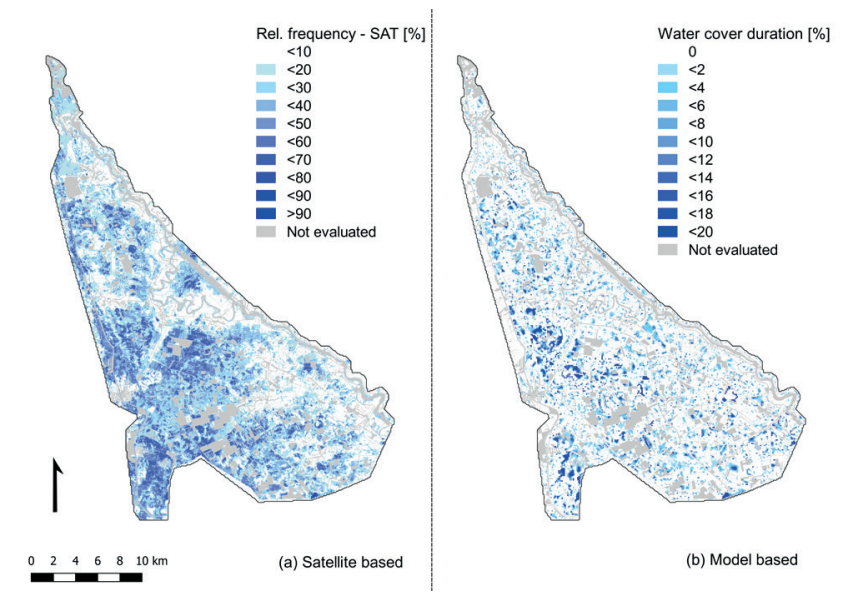

Fig. 4 Excess water hazard maps of the Szamos-Kraszna Interfluve: (a) Satellite imagery based relative frequency map, showing the relative number of inundations from 5-6 events between 1998-2016, created by: Lechner Kft.); (b) Hydrological simulation based hazard map (showing the relative number of days with inundation between the 1980-2010 period, created by: BME VKKT, WR IHM)

\subsubsection{Evaluation of the drainage network}

Regarding the performance of the channel system, three main questions were listed in Section 2.2. Based on the results of the hydrological model simulations we answer these in the followings.

Question (i): The proportion of surface and subsurface waters in the drainage turned out to vary from event to event, with the overall average to be $39 \%$ surface to $61 \%$ subsurface water. The high ratio of surface water originates from the design of the channel network (Fig. 1), which transects many terrain depressions and thus directly gathers the locally accumulated ponding waters. By draining subsurface waters as well, the channel network has a lowering effect on the groundwater table and therefore also indirectly affects the amount of water surplus in locations further away from the channels. The 39:61\% ratio indicates that both direct and indirect drainage processes play a major role in excess water defense. It also points out the significant, spatially extensive capability of the channel network to remove valuable water resources not only from the inundated areas, but also from less affected locations.

Question (ii): According to the water budget of the 23 selected events, the average proportion of the four main processes leading to the elimination of surface water coverage turned out as 49\% infiltration, 32\% evapotranspiration, and drainage driven solely by gravity $(12 \%)$ or by pumping of water $(7 \%)$. Compared to the natural hydrological processes, human interventions have only a moderate impact $(19 \%)$ on the outcome of the actual extreme events. Great variations occurred between certain events here as well. 
Question (iii): Fig. 5 shows the dynamics of water coverage with and without drainage over the 30 years long simulation period. Most excess water events can be clearly identified, although in some cases it is difficult to separate one event from another as the earlier inundation does not disappear completely until the following one occurs (e.g., 1980-1981 or 1998-1999). A typical temporal pattern can also be recognized in most of the cases: First, water coverage appears with a sharp increase in December-January. Then it might stagnate, if the temperature is below freezing point, which inhibits infiltration. New superposed spikes of inundation might also turn up as a result of rainfall events. Finally, water coverage disappears in an approximately first order decay pattern. The speed of disappearance is influenced first of all by air temperature, a control variable for both infiltration and potential evapotranspiration.

The role of the channel network is illustrated by the two time series of Fig. 5. The operation of the channel network reduces the inundated areas with an average of $\sim 1 \mathrm{ha} / \mathrm{km}$ (or $1 \%$ ). The reducing effect is loosely correlated to the extent of inundation (the larger the water coverage, the larger the difference). The maximum difference between drained and undrained cases appeared at the peak inundation of 1999 and was $4.6 \mathrm{ha} / \mathrm{km}(4.6 \%)$. The duration of the selected 23 excess water events was reduced by an average of 20 days (the mean duration changed from 118 to 98 days), which means an average of $\sim 20 \%$ decrease.
These numbers indicate that the drainage network itself cannot eliminate the hydrological extremity. It has a moderate influence on the temporal extent of inundation events, but only a minor effect on the spatial extent. This quantitative founding is in line with the field experience of regional water directorates [44]. It is also noteworthy that there is an almost continuous water coverage in the Present-without drainage scenario. This is in line with the fact that prior to it's canalization, the region used to be a marshland. It also suggests that the landscape still has its hydrological potential for wetland revitalization.

In their analysis, [45] came to similar finding about the channel network. They used integrated hydrologic modelling to assess the possible effects of an alternative water management in a $13 \mathrm{~km}^{2}$ lowland catchment located on the Sand Ridge (Hungary). The authors found that the partial closure of the $6.5 \mathrm{~km}$ long drainage channel network would lead to locally elevated groundwater levels. With different scenarios, they were able to delineate the drainage area of the channel network. The analysis showed that a compromise is possible between the revitalization of the local nature protection areas and the needs of the surrounding croplands.

Our answers for the Questions (i)-(iii) raise some fundamental issues considering the drainage-focused water management strategy of the recent decades. First, still thinking within the old paradigm, how and to what aim should be


Fig. 5 Comparison of simulated water coverage time series for the Scenario 1. (Present-reference, with drainage) and Scenario 2. (Present-no drainage). The water coverage is summed for the total study site area, the $[\mathrm{ha} / \mathrm{km}]$ dimension is equivalent to percentage [\%] 
the limited defense capacity reallocated? Considering the threatened material goods, it is obvious that the protection of the settlements and other infrastructure should have the highest priority. The further judgement of the question requires a detailed risk based approach, where hazard, vulnerability and economic value together should define the priority of certain locations [43]. Furthermore, while the drainage system offers only minor-moderate mitigation capacity for certain inland excess water events, on the long run it removes significant amount of water from the affected catchments, resulting in lowering groundwater levels and increasing drought sensitivity [5]. This leads to the water surplus-water scarcity paradox, which was outlined in the Introduction. To find adequate answers for this challenge, a land use-water management paradigm change is required, which focuses on water retention in the landscape and evaluates the role of hydrology in the context of the ecosystem services approach.

\subsection{Ecosystem services}

Scenarios 3. and 4. were used to test the validity of the proposed water retention paradigm. Regarding hydrological conditions, the main outcome was that actual evapotranspiration (ET) was $8 \%$ higher in the Control-alternative scenario $(644 \mathrm{~mm} /$ year versus $594 \mathrm{~mm} /$ year of the Controlreference). This can be explained (i) by the systematic excess water and flood retention within the study site and (ii) by larger forested areas with deeper root zone (Table 1), which provide a higher rate of transpiration. While subsurface water provided two-thirds (404 mm/year) of ET in case of the Control-reference, its contribution shrank to $56 \%$ in the alternative scenario (364 $\mathrm{mm} /$ year), the rest being provided by interception and the retained surface waters. These numbers suggest a more humid microclimate and better conditions for water tolerant vegetation.

Fig. 6 compares the net profit values of the evaluated ES for two land use-water management approaches (the cellbased results of different ES were summarized for the whole study site and divided by the total area). The fading colors indicate the growing uncertainty of monetary valuation of ES. Private profit of arable land and pasture as well as social benefits of carbon sequestration and flood regulation are among the more precisely estimated ES (Section 2.3). The other social benefits of the various land use categories are harder to evaluate and therefore are only rough estimates.

While the total value of agricultural production was higher for present conditions, it is only the result of larger cropland area (Table 1). The area specific yields ( $\mathrm{t} / \mathrm{ha}$ )

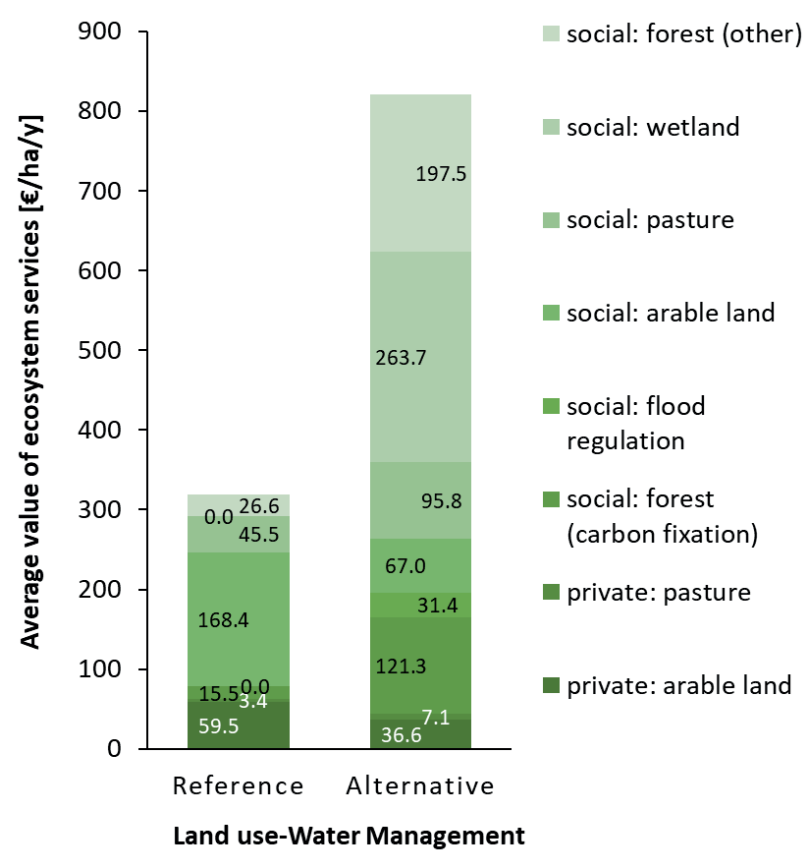

Fig. 6 Comparison of the evaluated ecosystem services for the Controlreference (present conditions) and Control-alternative (adaptive land use-water management) scenarios

turned out to be $18 \%$ higher for the alternative scenario, which can be explained with the better water availability at the remaining croplands of the adaptive landscape. Therefore, the $65 \%$ reduction of cropland area caused only a $40 \%$ decrease in agricultural profit.

Considering all private profit, the present land use is more favorable. However, when taking into account other social benefits, the alternative strategy comes to first place with more than a doubled total value of all ES. Those social benefits, which are evaluated only implicitly in this study include microclimate regulation, soil erosion protection, water quality regulation, biodiversity improvement and a number of cultural ES. The following ES ranking resulted for the evaluated land use type (in increasing order): croplands, pastures-meadows, forests and wetlands.

Beside its hydrological and economical relevancy, the result of this scenario comparison has also a nature conservation aspect. Biró et al [46] identified major ecological decline in the form of continuous habitat loss in Hungary in the last 230 years, which affected not only natural but semi-natural habitats (grasslands, woodlands, wetlands) as well. They found that habitat loss could be effectively halted by conservation measures but only in protected areas.

As Mihók et al. [47] pointed out, agricultural intensification, decreasing farmland biodiversity, climate change and groundwater decline are posing serious challenges for successful and widespread conservation efforts in 
Hungary. They urge more sustainable water management and adaptive land use practices in order to cope with these challenges. The introduced hydrology-ecosystem service focused analysis can be a useful tool to assess such conservation efforts as well. Beside its higher social benefits, the proposed alternative land use-water management scenario offers also greater success for nature protection.

\section{Conclusions}

The presented methodology enabled us to compare two distinct land use-water management strategies for a lowland catchment prone to hydrological extremities. The results suggest that the classic "water surplus-water scarcity" paradox of the Great Hungarian Plain could be resolved to some degree with adaptive measures.

The calibrated hydrological model simulations of the study site showed that the drainage system could reduce the extent and duration of inland excess water moderately. This means that from the hydrological point of view, the current water management practice has only a limited capacity to provide the needs of the intensive cropland dominated land use pattern. Furthermore, the evaluated

\section{References}

[1] Szatmári, J. (ed.) "Belvíz" (Inland Excess Water), University of Szeged, Department of Natural Geography and Geoinformatics, University of Novi Sad, Faculty of Science, Szeged, Hungary, Novi Sad, Serbia, 2013.

https://doi.org/10.13140/2.1.5143.3920

[2] Bozán, Cs., Takács, K., Körösparti, J., Laborczi, A., Túri, N., Pásztor, L. "Integrated spatial assessment of inland excess water hazard on the Great Hungarian Plain", Land Degradation and Development, 29(12), pp. 4373-4386, 2018.

https://doi.org/10.1002/ldr.3187

[3] Mezősi, G. "The Physical Geography of Hungary", Springer, Cham, Switzerland, 2009.

https://doi.org/10.1007/978-3-319-45183-1

[4] FAO "FAOSTAT Data Retrieval Site" [online] Available at: http:// www.fao.org/faostat/en/\#data/QC [Accessed: 13 April 2021]

[5] Pinke, Zs., Decsi, B., Kozma, Zs., Vári, Á., Lövei, G. L. "A spatially explicit analysis of wheat and maize yield sensitivity to changing groundwater levels in Hungary, 1961-2010", Science of the Total Environment, 715, Article No. 136555, 2020.

https://doi.org/10.1016/J.SCITOTENV.2020.136555

[6] Szesztay, K. "The Role of Water in Landscape Ecology and in Crop Production", Periodica Polytechnica Civil Engineering, 38(3), pp. 315-331, 1994. [online] Available at: https://pp.bme.hu/ci/article/ view/3797

[7] Directorate-General for Environment "Mapping and Assessment of Ecosystems and their Services: An analytical framework for mapping and assessment of ecosystem condition in EU", European Commission, Brussels, Belgium, Rep. 2018-001, 2018.

https://doi.org/10.2779/12398 total value of several ecosystem services turned out to be greater for the adaptive land use strategy, which focuses on water retention. Taking into account the different environmental aspects (hydrological processes, climatological and ecological pressures), the need for a strategy change is obvious. Scenario analysis aided by hydrological modelling is a proper method for strategic planning.

\section{Acknowledgement}

Development of the WateRisk model system and the related work was undertaken as part of the WateRisk projects. Sponsor: National Development Agency (TECH08-A4/2-2008-0169).

The research reported in this paper and carried out at BME has been supported by the NRDI Fund (TKP2020 IES, Grant No. TKP2020 BME-IKA-VIZ) based on the charter of bolster issued by the NRDI Office under the auspices of the Ministry for Innovation and Technology.

We are grateful for the Lechner Nonprofit Kft., Department of Remote Sensing and Land Offices for providing us their satellite imagery based excess water hazard map for the study area.

[8] Stosch, K. C., Quilliam, R. S., Bunnefeld, N., Oliver, D. M. "Quantifying stakeholder understanding of an ecosystem service trade-off", Science of the Total Environment, 651(2), pp. 25242534, 2019.

https://doi.org/10.1016/j.scitotenv.2018.10.090

[9] Derts, Zs., Koncsos, L. "Ecosystem services and land use zonation in the Hungarian Tisza deep floodplains", Pollack Periodica, 7(3), pp. 79-90, 2012.

https://doi.org/10.1556/Pollack.7.2012.3.8

[10] Staes, J., Rubarenzya, M. H., Meire, P., Willems, P. "Modelling hydrological effects of wetland restoration: A differentiated view", Water Science and Technology, 59(3), pp. 433-441, 2009. https://doi.org/10.2166/wst.2009.884

[11] Pinke, Zs., Kiss, M., Lövei, G. L. "Developing an integrated land use planning system on reclaimed wetlands of the Hungarian Plain using economic valuation of ecosystem services", Ecosystem Services, 30(B), pp. 299-308, 2018. https://doi.org/10.1016/j.ecoser.2017.09.007

[12] Decsi, B., Vári, Á., Kozma, Zs. "The effect of future land use changes on hydrologic ecosystem services: a case study from the Zala catchment, Hungary", Biologia Futura, 71(4), pp. 405-418, 2020 .

https://doi.org/10.1007/s42977-020-00032-6

[13] European Parliament and the Council of the European Union, Directive 2000/60/EC of the European Parliament and the Council of the of 23 October 2000 establishing a framework for Community action in the field of water policy, Official Journal of the European Union, L 327/1, pp. 0001-0073, 2000. 
[14] Boswell, J. S., Olyphant, G. A. "Modeling the hydrologic response of groundwater dominated wetlands to transient boundary conditions: Implications for wetland restoration", Journal of Hydrology, 332(3-4), pp. 467-476, 2007. https://doi.org/10.1016/j.jhydrol.2006.08.004

[15] Mitsch, W. J., Bernal, B., Hernandez, M. E. "Ecosystem services of wetlands", International Journal of Biodiversity Science, Ecosystem Services and Management, 11(1), pp. 1-4, 2015. https://doi.org/10.1080/21513732.2015.1006250

[16] Ungvári, G., Jolánkai, Zs., Kis, A., Kozma, Zs. "The Feasibility of Cooperation to Comply with Land Use Change Obligations in the Marosszög Area of South Hungary", Journal of Environmental Geography, 11(3-4), pp. 37-47, 2018. https://doi.org/10.2478/jengeo-2018-0011

[17] Koncsos, L. (ed.) "WateRisk - Jövőképtől a vízkészlet-kockázatig" (WateRisk- From Future Vision to Water Resource Risk), Budapest University of Technology and Economics, Department of Sanitary and Environment Engineering, Budapest, Hungary, 2011. [online] Available at: https://www.researchgate.net/publication/331175928 (in Hungarian)

[18] Central Directorate for Water and Environment "The overflow reservoirs of Tiszaroff" [pdf] Central Directorate for Water and Environment, Budapest, Hungary, Available at: https://www.vizugy. hu/uploads/csatolmanyok/161/kiadvany_en.pdf [Accessed: 13 April 2021]

[19] Kozma, Zs., Koncsos, L., Jolánkai, Zs., Kardos, M., Koncsos, T., Muzelák, B., Parditka, G., Liska, B., Derts, Zs. "Overview of risk based water resources scenario analysis - the WateRisk decision support system", presented at 6th IWA International Conference for Young Water Professionals, Budapest, Hungary, July, 10-13, 2012. [online] Available at: https://www.researchgate.net/publication/331327441_Overview_of_risk_based_water_resources_scenario_analysis-the_WateRisk_decision_support_system

[20] Bossard, M., Feranec, J., Otahel, J. "CORINE land cover technical guide - Addendum 2000", European Environment Agency, Copenhagen, Denmark, Rep. 40/2000, 2000.

[21] Christensen, J. H., Carter, T. R., Giorgi, F. "PRUDENCE employs new methods to assess European climate change", Eos, Transactions American Geophysical Union, 83(13), pp. 146-147, 2002. https://doi.org/10.1029/2002EO000094

[22] Bakacsi, Zs., Pásztor, L., Szabó, J., Kuti, L, Laborczi, A. "3D textúra adatbázis létrehozása indikátor-krigeléssel, talajtani és agrogeológiai adatbázisok egységesítésével" (Compilation of 3D soil texture dataset applying indicator kriging method, integrating soil and agrogeological databases), Journal of Agricultural Informatics, 3(1), pp. 46-51, 2012. (in Hungarian)

https://doi.org/10.17700/jai.2012.3.1.60

[23] Kozma, Zs. "Belvízi szélsőségek kockázatalapú értékelésének és modellezési módszertanának fejlesztése" (Development of the risk based evaluation and modeling methodology of excess water extremities), PhD Thesis, Budapest University of Technology and Economics, 2014. [online] Available at: https://repozitorium. omikk.bme.hu/bitstream/handle/10890/5576/ertekezes.pdf?sequence $=2 \&$ is Allowed $=y$ [Accessed: 13 April 2021]
[24] Breuer, L., Eckhardt, K., Frede, H.-G. "Plant parameter values for models in temperate climates", Ecological Modelling, 169(2-3), pp. 237-293, 2003.

https://doi.org/10.1016/S0304-3800(03)00274-6

[25] Jolánkai, Zs., Kardos, M., Koncsos, L., Kozma, Zs., Muzelák, B. "Pilot Area Studies in Hungary with a Novel Integrated Hydrologic Model-WateRisk", presented at 6th IWA International Conference for Young Water Professionals, Budapest, Hungary, July, 10-13, 2012. [online] Available at: https://www.researchgate.net/publication/331327353_Pilot_Area_Studies_in_Hungary_with_a_Novel_ Integrated_Hydrologic_Model-WateRisk

[26] Kozma, Zs., Koncsos, L. "Methodological overview of a coupled water resources management model system", In: Proceedings of the 13th International Conference on Civil, Structural and Environmental Engineering Computing, Chania, Greece, 2011, Paper 157. https://doi.org/10.4203/ccp.96.157

[27] Jolánkai, Zs., Koncsos, L. "The effects of terrain morphology model on excess water inundation and phosphorus transport modeling", Journal of Environmental Science and Engineering B, 2(12), pp. 728-735, 2013.

https://doi.org/10.17265\%2F2162-5263\%2F2013.12.007

[28] Kozma, Zs., Ács, T., Koncsos, L. "Unsaturated zone modelling: The role of soil database classification", WIT Transactions on Ecology and the Environment, 185, pp. 197-208, 2014.

https://doi.org/10.2495/SI140181

[29] Kardos, M., Koncsos, L. "Klímaváltozás és vízpótlás hatásainak vizsgálata a WateRisk integrált hidrológiai modellel egy DunaTisza közi mintaterületen" (Assessing climate change and water supply impacts on the Danube-Tisza Interfluve by the WateRisk Integrated Hydrologic Model), Hungarian Journal of Hydrology, 98(2), pp. 36-46, 2018, (in Hungarian).

[30] Csendes, B., Mucsi, L. "Inland excess water mapping using hyperspectral imagery", Geographica Pannonica, 20(4), pp. 191-196, 2016.

https://doi.org/10.18421/GP20.04-01

[31] Pálfai, I. "Belvizek és Aszályok Magyarországon. Hidrológiai tanulmányok" (Excess water and drought in Hungary. Hydrological studies), Közlekedési Dokumentációs Kft., Budapest, Hungary, ISBN 963552382 3, 2004. (in Hungarian)

[32] Kozma, Zs., Derts, Zs., Kardos, M., Koncsos, L. "A mezőgazdasági termelés mint ökoszisztéma-szolgáltatás értéke: Hidrológiai modellhez kapcsolt számítási módszertan" (The value of agricultural crops as an eco-system service: Calculation methodology connected to a hydrological model), Hungarian Journal of Landscape Ecology, 10(1), pp. 55-69, 2012. (in Hungarian) [online] Available at: http:// tajokologiailapok.szie.hu/eabstr8.html

[33] van Ittersum, M. K., Rabbinge, R. "Concepts in production ecology for analysis and quantification of agricultural input-output combinations", Field Crops Research, 52(3), pp. 197-208, 1997.

[34] Hungarian Central Statistical Office "Summary Tables STADAT - 19. Agriculture", [online] Available at: https://www.ksh.hu/stadat?lang=en\&theme=mez [accessed 13 April 2021]

[35] Kozma, Zs., Karakai, T., Derts, Zs., Ungvári, G. "Enrichment of the natural capital by reforestation: Algorithm and first case study results", presented at 6th IWA International Conference for Young Water Professionals, Budapest, Hungary, July, 10-13, 2012. 
[36] Koncsos, L., Balogh, E. "Flood damage calculation supported by inundation model in the Tisza Valley", In: 32nd Congress of the International Association of Hydraulic Engineering and Research (IAHR), Venice, Italy, 2007, Paper: SS05-12-O.

[37] Eszlári, N., Marjainé Szerényi, Zs. "Land use change as an opportunity to decrease the consequences of extreme weather events: a case study of the Tisza Valley in Hungary", Economic and Environmental Studies, 14(4), pp. 389-412, 2014. [online] Available at: https:// czasopisma.uni.opole.pl/index.php/ees/article/view/2910/2352

[38] Đukić, V, Erić, R. "SHETRAN and HEC HMS Model Evaluation for Runoff and Soil Moisture Simulation in the Jičinka River Catchment (Czech Republic)", Water, 13(6), Article No. 872, 2021. https://doi.org/10.3390/w13060872

[39] Đukić, V., Erić, R., Dumbrovsky, M., Sobotkova, V. "Spatiotemporal analysis of remotely sensed and hydrological model soil moisture in the small Jičinka River catchment in Czech Republic", Journal of Hydrology and Hydromechanics, 69(1), pp. 1-12, 2021. https://doi.org/10.2478/johh-2020-0038

[40] Právetz, T., Sipos, Gy., Benyhe, B., Blanka, V. "Modelling Runoff on a Small Lowland Catchment, Hungarian Great Plains", Journal of Environmental Geography, 8(1-2), pp. 49-58, 2015. https://doi.org/10.1515/jengeo-2015-0006

[41] van Leeuwen, B., Právetz, T., Liptay, Z. Á., Tobak, Z. "Physically based hydrological modelling of inland excess water", Carpathian Journal of Earth and Environmental Sciences, 11(2), pp. 497510, 2016. [online] Available at: http://www.cjees.ro/viewTopic. php?topicId $=636$
[42] Nádor, G., Mikus, G., Surek, G. "Relatív belvíz gyakorisági térkép elöállítása" (Development of an Inland Excess Water Relative Frequency Map), Budapest Goverment Bureau, Department of Geodesy, Remote Sensing and Land Registry, Budapest, Hungary, 2017. (in Hungarian)

[43] Kron, W. "Flood risk = hazard • values • vulnerability", Water International, 30(1), pp. 58-68, 2005.

https://doi.org/10.1080/02508060508691837

[44] Bíró, T. "A hazai belvízkutatás néhány időszerű kérdése" (Some Timely Issues of Excess Surface Water Research in Hungary), Hungarian Journal of Hydrology, 96(2), pp. 5-12, 2016. (in Hungarian)

[45] VITUKI Hungary Kft. "Kunpeszér térségében található csatornák üzemeltetésének hatásai a környező területek talajvízszintjére" (The effect of drainage channel management on groundwater levels of the surrounding areas of Kunpeszér), VITUKI Hungary Kft., Budapest, Hungary, Rep. 0715/2016, 2015. (in Hungarian)

[46] Biró, M., Bölöni, J., Molnár, Zs. "Use of long-term data to evaluate loss and endangerment status of Natura 2000 habitats and effects of protected areas", Conservation Biology, 32(3), pp. 660-671, 2018. https://doi.org/10.1111/cobi.13038

[47] Mihók, B., Biró, M., Molnár, Zs., Kovács, E., Bölöni, J., Erős, T., Standovár, T., Török, P., Csorba, G., Margóczi, K., Báldi, A. "Biodiversity on the waves of history: Conservation in a changing social and institutional environment in Hungary, a post-soviet EU member state", Biological Conservation, 211(A), pp. 67-75, 2017. https://doi.org/10.1016/j.biocon.2017.05.005 